\title{
Cloud Communities: The Dawn of Global Citizenship?
}

\author{
Liav Orgad
}

\section{The idea of global citizenship}

About 70 years ago, an American peace activist named Garry Davis created a registered concept of 'world citizenship.' A naïve enterprise at its infancy, this concept looks more realistic today for three reasons. The first reason is global interconnectedness. The internet has profoundly changed the notion of public space. About 50 per cent of the world population uses the internet and global internet use is consistently growing - from 16 per cent in 2005 to 48 per cent in 2017. 71 per cent of the world's youth population (15-24) uses the internet, 94 per cent in the developed world. ${ }^{1} 2.3$ billion people use smartphones, almost one-third of the global population. Facebook and WeChat in China have an estimated 3 billion users together. Internet technologies and cloud computing enable people to establish digital IDs, which could eventually become recognised as an international legal personality, be connected with one another, disentangled from physical borders, and act at a distance.

The second reason is identity. Ever since Aristotle, membership in a political community denotes an identity of some kind. Shared identity is a cornerstone of citizenship - it creates a sense of community and a commitment toward a common good. ${ }^{2}$ While the idea of global citizenship goes back to ancient Greece - the Greek philosopher Diogenes is credited to be the first to define himself as 'a citizen of the world' ${ }^{3}-$ it is only in recent

\footnotetext{
1 International Telecommunications Union (2017), ITU Facts and Figures. Geneva: International Telecommunications Union, available at https://www.itu. int/en/ITU-D/Statistics/Documents/facts/ICTFactsFigures2017.pdf

2 Joppke, C. (2010), Citizenship and Immigration. Cambridge: Polity Press.

3 Nussbaum, C. M. (1994), 'Patriotism and cosmopolitanism', The Boston Review.
}

The research is supported by the European Research Council (ERC) Starting Grant (\# 716350). I thank Ehud Shapiro and Primavera De Filippi for inspiring discussions on the concept of self-sovereign digital identity. 
years that a transformation of consciousness from local to global identities has been identified. Recent polls reveal that people are increasingly identifying themselves as global, rather than national, citizens. For example, a 2016 BBC World Poll shows that 56 per cent of the respondents consider themselves, first and foremost, as 'global citizens,' rather than national citizens. ${ }^{4}$ A 2016 World Economic Forum Survey indicates that the vast majority of young people identify themselves first as 'human' ( 40.8 per cent) and 'citizens of the world' ( 18.6 per cent), while national identity only comes third (13 per cent). ${ }^{5}$ National identity remains central, but, particularly in emerging economies, a perception of global social identity is on the rise. ${ }^{6}$ For the first time in history, a large percentage of the world's population places global identity above any national or local identities; there is a growing sense of a global community that transcends national borders.

The third reason is responsibility, a central component of a republican conception of citizenship. In a republican view, members of a political community share public responsibilities to promote a common good and confront common challenges. Today, more than ever, human beings face common global challenges and human activities have a cumulative effect on the global scale. ${ }^{7}$ Although there are no global individual responsibilities, at least not in the legal sense, private individuals are increasingly showing global responsibility in different policy areas (food consumption, global warming, animal rights) by taking actions (e.g., buying organic food, recycling, becoming a vegetarian) based on free choice and without state coercion. Some of the global challenges have become urgent and cannot be adequately addressed on the national level. By showing global responsibility, even if limited and with a weak sense of agency, individuals are participating in activities whose scope and target audience go beyond

4 GlobeScan (2016), Global Citizenship a Growing Sentiment Among Citizens of Emerging Economies: Global Poll. Available at https:/www.globescan.com/ news-and-analysis/press-releases/press-releases-2016/383-global-citizenshipa-growing-sentiment-among-citizens-of-emerging-economies-global-poll.html

5 World Economic Forum (2017), Global Shapers Annual Survey 2017. Available at http://www.shaperssurvey2017.org/static/data/WEF_GSC Annual_Survey_2017.pdf; World Economic Forum (2016) Globäl Shāpers Annual Survey 2016. Available at http://www.shaperssurvey2017.org/static/ data/GSC_AS16_Report.pdf

6 Buchan, N., M. B. Brewer, G. Grimalda, R. K. Wilson, E. Fatas \& M. Foddy (2011), 'Global social identity and global cooperation', Psychological Science 22 (6): 821-828.

7 Dower, N. (2003), 'Does Global Citizenship Require Modern Technology?' Ideas Valores 52 (123): 25-42. 
national boundaries. The changing public opinion thus goes hand in hand with changes in individual actions motivated by a sense of global political responsibilities.

\section{Status: international legal persona}

Under the current structure of international law, individuals exist as legal persons only through a status conferred to them by a state. Individuals are citizens or residents of some state; an international legal status of a 'human being' is non-existent. ${ }^{8}$ True, international law speaks in universal terms of international human rights law, even natural rights, but it makes them largely dependent on citizenship and territorial sovereignty, as if a person only legally exists through a state - a feudalist approach. ${ }^{9}$ This state of affairs raises three issues. First, human rights: an estimate of 1.1 billion people, 15 per cent of the world population, lacks an official identification. ${ }^{10}$ Without a national identification, one cannot have access to basic services and participate in modern life; one lacks, as coined by Hannah Arendt, the 'right to have rights'. For refugees and displaced persons, having no national identity can lead to detention and deportation. But even people with a national ID may wish to have a universal ID that allows them to choose an identity free of state limitations (think of national restrictions on gender identity, sexual orientation, and names). The legal source for an international legal personality can be found in Article 6 of the Universal Declaration of Human Rights, according to which 'Everyone has the right to recognition everywhere as a person before the law' (also Article 16, ICCPR). ${ }^{11}$

The second issue is lack of self-governance. Existing citizenship regimes are based on Westphalian sovereignty under which citizens govern their life

8 It has a few exceptions: individual criminal responsibility and some civil liabilities in international law.

9 Benhabib, S. (2005), 'Borders, Boundaries, and Citizenship', Political Science and Politics 38 (4): 673-677.

10 Desai, V., M. Witt, K. Chandra \& J. Marskell (2017), 'Counting the uncounted: 1.1 billion people without IDs', The World Bank. Available at http://blogs. worldbank.org/ic4d/counting-uncounted-11-billion-people-without-ids

11 United Nations (1948), Universal Declaration of Human Rights. Available at http://www.un.org/en/universal-declaration-human-rights/; Also: United Nations (1966), International Covenant on Civil and Political Rights. Adopted by the General Assembly of the United Nations on 19 December 1966, available at https://treaties.un.org/doc/publication/unts/volume\%20999/volume999-i-14668-english.pdf 
indirectly - through the state. ${ }^{12}$ This means that the status of citizenship perpetuates the monopoly of the state to control the exercise of individual rights. On the national level, the exercise of rights is connected with the status of citizenship (though less today than in the past) ${ }^{13}$ on the transnational level, following the development of a standard travel document, the passport, the exercise of freedom of movement outside the state has become connected with citizenship (perhaps more so today than in the 18th and 19th centuries).$^{14}$ It also means that the participation of individuals in international law-making, even in decisions that directly affect them, is only realised through state representatives and depends a great deal on who is included in the boundaries of the demos. Minorities that have minimal political influence or no citizenship rights remain unheard in international decision-making, and so are people who are ineligible to vote in national elections due to electoral law restrictions and citizens in authoritarian regimes. ${ }^{15}$ The actual influence of individuals in the creation of international law is infinitesimally small.

The third issue is unequal representation. Since the 17th century, the Westphalian concept of sovereignty has been based upon two fundamental ideas that have marched together - nation-states and territories - accompanied by a third idea, equality: the notion that sovereign states are equal. ${ }^{16}$ The Peace of Westphalia ended the medieval hierarchical system of power among rulers - though not among humans - and replaced it with a system of territorial sovereignty and sovereign equality of states (this idea is recognised today in Article 2(1) to the UN Charter). ${ }^{17}$ Unlike sovereign states, individuals do not have an equal voice in international affairs. International law is organised on a 'one-state, one-vote' basis - a system that creates disparities in individual voting power. Citizens of San Marino (33,000 people)

12 Peters, A. (2016), Beyond human rights: the legal status of the individual in international law. New York: Cambridge University Press (Huston J. tran.).

13 Spiro, P. (2008), Beyond Citizenship: American Identity After Globalization. New York: Oxford University Press.

14 Dehm, S. (2018), 'The Passport', in Hohmann J. \& D. Joyce (eds.), The Objects of International Law. Oxford: Oxford University Press (forthcoming).

15 Shaw, J. (2017), 'Citizenship and the Franchise', in Shachar A., R. Bauböck, I. Bloemraad \& M. Vink (eds.), The Oxford Handbook of Citizenship, 290-313. Oxford: Oxford University Press.

16 Walker, N. (2017), 'The Place of Territory in Citizenship' in A. Shachar, R. Bauböck, I. Bloemraad \& M. Vink (eds.), The Oxford Handbook of Citizenship, 553-575. Oxford: Oxford University Press.

17 United Nations (1945), Charter of the United Nations. Available at http://www. un.org/en/sections/un-charter/chapter-i/index.html 
have the same voting power in the UN as citizens of India (1.2 billion). The disparity in individual voting power in governance of global issues (e.g., global warming and the environment) undermines the equal value of citizenship under international law.

\section{Digital identity: blockchain technology}

The UN Sustainable Development Goals recognise the importance of legal identity for all. Article 16.9 aims to 'provide legal identity for all, including birth registration' by 2030. Through the ID4D program, the World Bank assists in the promotion of the UN goal by financially assisting states to provide recognised IDs. ${ }^{18}$

The internet already offers the infrastructure for the realisation of digital IDs, yet new technologies, e.g. blockchain, are likely to bring further improvements necessary to turn the idea into reality. The internet is a system of interconnected computer networks, which allows for exchange and transfer of data. All present major internet applications are structured in a clientserver application, where the participants access it via an app or a web browser (client) and the company providing the application runs the computations and data on their own computers (server). This structure gives these companies (and governments) total control over the service they provide and all the data produced by its users. Blockchain technology offers the first internet applications that works differently; it is designed as a peer-to-peer system that is not controlled by a central entity and in which data exchange is not stored in a single physical location. On the blockchain, shared data are hosted by all the computers in the network simultaneously and are publicly accessible to all. Blockchain technology is a game changer; it can provide people with self-sovereign identity - they are the ones who create and register their identity and they are the only ones who control what to do with it and with whom to share what. In such a decentralised system, one's identity is not owned by a central server (Facebook, LinkedIn, a state ministry), but by the person herself; she can decide which data to share and for what purpose. Hence, blockchain technologies can help achieving the UN goal of granting an ID to everyone, not just to those who can obtain it from a state, in a decentralised way that is not necessarily controlled by the UN or by states.

18 Above n.11. 
Several organisations are currently working on the creation of the technological infrastructure required for a trustworthy global digital ID. ${ }^{19}$ The achievement of this goal involves some challenges: who will register people for a global ID? What will be the relation between a global ID and a national ID - will the global ID rely on national registries or be independent? When will a global ID be created - at birth, or at later age when the person can exercise control? Which details will be included - only a birth certificate, or also physical characteristics and biometric data? Will there be a standard form? Will the possession of a global ID be a right, or also a duty? How to create digital IDs for people in places where the required technology does not exist or in authoritarian regimes that restrict their subjects' access to information technology? How to create an ID that is immune to identity theft and fake identities? These are important questions, but the very idea of a global digital identity for everyone, giving all people a legal status as a 'human being,' is no longer a far-fetched possibility.

A global ID is not a status of citizenship - nor does it create, in and of itself, an international legal status, although it is a prerequisite for it. Yet, in my view, this is not supposed to be its main purpose. An international legal persona should not be seen as a replacement of national citizenships but rather as a status and identity complementary to national citizenships (it is thus not identical to cosmopolitan visions of global citizenship) ${ }^{20}$. It is a legal concept that will provide everyone with a global unique ID of a 'human being.' This status will be the default lifelong identity and membership for every person, which cannot be waived or withdrawn, and on top of it individuals will have other forms of membership, such as national citizenship. $^{21}$

19 E.g., ID2020; uPort; Accenture Unique Identity Service Platform;

BITNATION; Democracy Earth Foundation, Jolocom, Evernym, Decentralized Identity Foundation.

20 See discussions in: Shachar, A. (2009), The Birthright Lottery: Citizenship and Global Inequality. Cambridge: Harvard University Press, 45-48.

21 My focus is on a formal legal institution - status - and the political deliberation that can follow it. Other issues that may be associated with an international legal status - e.g., rights (think of global basic income), duties (think of global tax system), or identity (think of global core curriculum) - require a different discussion. 


\section{Political participation: 'Cloud Communities'}

Imagine that every person has a trustworthy unique international legal persona; what are we going to do with it? The range of applications is enormous. The question is not only which functions are technologically possible, but which ones are normatively desirable, i.e., which values should be achieved by using technology?

In international law, a 'state' possesses four qualities: a permanent population, a defined territory, government, and a capacity to enter into relations with other states (Article 1, Montevideo Convention, 1933) ${ }^{22}$. International law does not recognise the concept of a 'virtual state,' yet existing virtual communities, such as Bitnation (https://bitnation.co/) - a decentralised borderless virtual nation that functions as a government service platform - challenge the definition of a 'state,' and raise the question of why some of the institutional functions of the state, for which it was first established, cannot be effectively served also by a virtual political community? ${ }^{23}$ Can we interpret a 'defined territory' to include cyberspace, or instead talk of 'state-like' non-territorial polities?

The concept of an international legal persona will enable individuals to establish 'Cloud Communities' of different kinds. Conceptually, cloud communities have traditional characteristics of political communities, but not necessarily a physical territory. The communal bond can be global in nature - such as a shared concern about climate change, ageing, veganism and animal rights (i.e., a universal community, open to everyone) - or ascriptive, such as a Jewish / Bahá'i faith / Diasporic Cloud Nations, a form of 'transnational nationalism' (i.e., a selective community, open only to certain members). It can be thematic or geographic - region, country, state, city, village - based on a shared interest or territorial identity, even if not corresponding to existing borders or legally recognised communities. Membership is based on consent; a person can be a member of several communities or none. The goal varies, but my focus is political communities. Cloud communities are not social networks, but political communities whose aim is political decision-making and in which individuals take part in a process of governance and the creation of law. The legal source for it can be Article

22 Convention signed at Montevideo December 26, 1933. Available at http:// avalon.law.yale.edu/20th_century/intam03.asp

23 Tarkowski Tempelhof, S., E. Teissonniere, J. Fennell Tempelhof \& D. Edwards (2017), Bitnation, Pangea Jurisdiction and Pangea Arbitration Token (PAT):

The Internet of Sovereignty. Planet Earth: Bitnation. 
25(1) of the International Covenant on Civil and Political Rights (ICCPR), according to which 'every citizen shall have the right and the opportunity ... to take part in the conduct of public affairs, directly or through freely chosen representatives.' Such a community may function in four areas: law (constitution, membership acquisition, registry), governance (political institutions, diplomacy, international agreements, taxes), welfare services (education, healthcare, social security), and economy (trade, corporate activities, fees). It can provide an ID registry, a dispute resolution system, collaborative decision-making, a virtual bank, and a voting system. In a sense, religions are a form of 'cloud communities': virtual and borderless, but not voluntary and decentralised.

Procedurally, cloud communities can be established in two ways. A topdown community can be set up by an international organisation, such as UN organs, as an advisory body to an existing UN organ (WHO, FAO, UNESCO), or in policy areas of global importance (the 17 UN Sustainable Development Goals is a good start). A bottom-up community can be set up by any number of international legal personas on a topic of common interest; as time passes by and the community reaches a certain numerical threshold, it can apply for a 'Consultative Status' at the UN (Article 71, UN Charter ${ }^{24}$ ). As in other mechanisms of advisory decision-making (e.g., advisory referendum), the outcome may become politically, even if not legally, binding.

Cloud communities are not a replacement for the state, but they offer global citizens sharing a common goal, interest, or identity new ways of interacting and collaborating with each other; they are 'state-like' entities.

\section{The future of citizenship: dynamic and multilayered?}

In today's world, one is a participating member in multiple political communities, each of which has different functions and comes with a different set of rights and duties. Citizenship is multilayered. ${ }^{25}$ It is, for example, national and supranational, as demonstrated by European Union citizenship

24 Available at http://www.un.org/en/sections/un-charter/un-charter-full-text/

25 Bauböck, R. (2017), 'Political Membership and Democratic Boundaries', in Shachar, A., R. Bauböck, I. Bloemraad \& M. Vink (eds.), 60-82. The Oxford Handbook of Citizenship. Oxford: Oxford University Press. 
or - quite differently - an African Union passport. ${ }^{26}$ It can be territorial and digital, as demonstrated by e-Estonia (https://e-estonia.com/), the first digital residency program in the world. In the blockchain-based digital society of e-Estonia, everyone can acquire e-residency in Estonia in order to access its digital governmental services; e-residents can establish a business in Estonia, register a company, participate in an e-school, open a bank account, and have an Estonian digital ID (e-residents are not entitled to physical residency in Estonia unless they fulfil the regular visa requirements - thus, they are e-residents without physical residency rights.) In July 2017, there were more e-residents than newborns in Estonia ${ }^{27}$ and the country is planning is to reach 10 million e-residents by 2025 , which will make its virtual population almost ten times larger than its territorial population (1.3 million in 2017).

Existing attempts to create 'cloud communities' - such as Bitnation and e-Estonia - already offer non-territorial forms of political membership, remodel the way people think about sovereignty, and challenge the definition of the state as we know it - as a legal entity that must have a physical territory and a centralised governance. ${ }^{28}$ Citizenship, à la Bitnation and e-Estonia, resembles a business model where states are service providers and 'citizens' are billed for the service - from education to healthcare to infrastructure. In this model, there is no lifetime membership but fixed membership contracts, which can be renewed or become permanent.

If we had to design a new international legal system, given today's political and technological conditions, would it be like the current system? The world is ready, more than ever before, for realising of one of the most morally-desirable notions in human history - global citizenship

26 The implementation of the African Union Passport, which is set to 2020, will facilitate the notion of an international legal persona as it would provide a legal identification to million Africans who currently lack a registered ID.

27 Fraga, D. (2017), 'The Birth of a Digital Nation in Estonia', Next Nature Network, August 30, available at https://www.nextnature.net/2017/08/ estonia-more-e-residents-than-babies/

28 Certainly, e-Estonia and Bitnation represent opposite functions of cloud communities. While e-Estonia uses new technologies to expand the global reach of a nation-state, Bitnation seeks to disrupt the current system by offering an anarchic post-nation state world of voluntary virtual communities. I thank Rainer Bauböck for this point. 
(Weltbürgerschaft) without a world state, as envisioned by Immanuel Kant in 1795. Such a vision is an addition to, and an improvement of the existing citizenship regimes that evolved in a completely different era. Are we ready to embrace the global citizenship that new technologies offer to us?

Open Access This chapter is licensed under the terms of the Creative Commons Attribution 4.0 International License (http://creativecommons.org/licenses/by/4.0/), which permits use, sharing, adaptation, distribution and reproduction in any medium or format, as long as you give appropriate credit to the original author(s) and the source, provide a link to the Creative Commons license and indicate if changes were made.

The images or other third party material in this chapter are included in the chapter's Creative Commons license, unless indicated otherwise in a credit line to the material. If material is not included in the chapter's Creative Commons license and your intended use is not permitted by statutory regulation or exceeds the permitted use, you will need to obtain permission directly from the copyright holder.

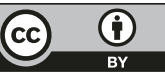

